The Role of the International Criminal Court in Preventing Atrocity Crimes through Timely Intervention 



\section{The Role of the International Criminal Court in Preventing Atrocity Crimes through Timely Intervention}

From the Humanitarian Intervention Doctrine and Ex Post Facto Judicial Institutions to the Notion of Responsibility to Protect and the Preventative Role of the International Criminal Court

Inaugural lecture as Chair in International Criminal Law and International Criminal Procedure at Utrecht University, delivered on 18 October 2010

by

Dr. Hector Olásolo 
Published, sold and distributed by Eleven International Publishing

P.O. Box 85576

2508 CG The Hague

The Netherlands

Tel.: +31 703307033

Fax: +31 703307030

e-mail: sales@budh.nl

www.elevenpub.com

Sold and distributed in USA and Canada

International Specialized Book Services

920 NE 58th Avenue, Suite 300

Portland, OR 97213-3786, USA

Tel: 1-800-944-6190 (toll-free)

Fax: +1 503 280-8832

orders@isbs.com

www.isbs.com

Eleven International Publishing is an imprint of Boom uitgevers Den Haag.

Cover photograph: ICC-CPI2006_49 031CICC-CPI Hans Hordijk

Lay-out: Wieneke Matthijsse

ISBN 978-94-90947-40-8

C 2011 H. Olásolo | Eleven International Publishing

This publication is protected by international copyright law.

All rights reserved. No part of this publication may be reproduced, stored in a retrieval system, or transmitted in any form or by any means, electronic, mechanical, photocopying, recording or otherwise, without the prior permission of the publisher.

Printed in The Netherlands 


\section{Rector Magnificus, ${ }^{1}$}

'[T]he brutal legacy of the twentieth century speaks bitterly' of the collective inadequacies of international institutions and 'the profound failure of individual States to live up to their most basic and compelling responsibilities. ${ }^{2}$ Given the profound and long-lasting costs to a society of engaging in atrocity crimes, ${ }^{3}$ strengthening preventative action becomes of utmost relevance. ${ }^{4}$ This is emphasised by the emerging notion of 'responsibility to protect'. ${ }^{5}$ In this inaugural lecture, I will address the role of the International Criminal Court (ICC) in implementing the notion of responsibility to protect through means other than ending impunity for past crimes.

\section{Humanitarian Intervention Doctrine and Responsibility to Protect}

The nineties saw the establishment, by the United Nations (UN), or with the direct involvement of the United Nations, of several international tribunals with jurisdiction over atrocity crimes that had already taken place. ${ }^{6}$ These tribunals were characterised by their primacy over national jurisdictions, their temporary nature, and the limitation of their jurisdiction to a specific crisis situation, such as the breakup of the former Yugoslavia or the

1 The author thanks Gordon Brandt and Margaret Wichmann for their research on legislation, case law and doctrine. The author is profoundly thankful to dr. Annemarieke Beijer, Wouter de Zanger and Wieneke Matthijsse, colleagues at the Willem Pompe Institute, for their work on the Dutch version of the present inaugural lecture. The views expressed herein are those of the author alone and do not necessarily reflect the views of the ICC, the ICTY, the United Nations in general or the Spanish Government.

2 United Nations General Assembly (UNGA) 'Implementing the Responsibility to Protect: Report of the Secretary-General' (12 Jan 2009) UN Doc A/63/677 paras 5, 6 [hereinafter UNGA, On Responsibility to Protect].

3 In this paper, the term 'atrocity crimes' includes the following crimes: genocide, crimes against humanity including ethnic cleansing, and war crimes. See in this regard, D. Scheffer, 'Atrocity Crimes Framing the Responsibility to Protect' (2007-2008) 40 Case Western Reserve Journal of International Law 111, 117 [hereinafter Scheffer, 'Atrocity Crimes']. See also D. Scheffer, 'Genocide and Atrocity Crimes' (2006) 1 Genocide Studies and Prevention 229, 238-9.

4 As UNGA, On Responsibility to Protect (Above n. 2) highlights at para 32, "[t]he difference between the two paths can amount to the choice between national potential preserved or destroyed.'

5 UNGA, On Responsibility to Protect (Above n. 2) at p. 2, paras 1-10.

6 A. Cassese, 'From Nuremberg to Rome: International Military Tribunals to the International Criminal Court', in: A. Cassese, A. Eser, G. Gaja, P. Kirsch, A. Pellet and B. Swart (eds.), The Rome Statute to the International Criminal Court, vol I (Oxford, Oxford University Press, 2002) 10-7. 
Rwandan genocide. ${ }^{7}$ As explained by Leila Sadat and Michael Scharf, they were part of a broader post-conflict UN strategy, and their primary goal was to facilitate reconciliation. ${ }^{8}$

Extending the basis for judicial intervention, while perpetuating a global system that tolerated atrocity crimes through inaction, was unsustainable. ${ }^{9}$ As a consequence, the nineties also saw the greatest development of the humanitarian intervention doctrine, and its application to situations such as those in Somalia in 1993 and Kosovo in 1999. ${ }^{10}$ This doctrine is based on the understanding of sovereignty as responsibility, which can be traced back to Francisco de Vitoria and Bartolomé de las Casas. Their ideas led to the 1542 New Laws of the Indies, which abolished native slavery for the first time in European colonial history. ${ }^{11}$ In the early seventeenth century, Jesuit Fran

7 R. Cryer, H. Friman, D. Robinson and E. Wilmshurst, An Introduction to International Criminal Law and Procedure (Cambridge, Cambridge University Press, 2007) 102-17 [hereinafter Cryer, An Introduction].

8 L. Sadat, 'The Legacy of the ICTY: The International Criminal Court' (2003) 37 New England Law Review 1073; V. Morris and M. Scharf, An Insider's Guide to the International Criminal Tribunal for the Former Yugoslavia, vol. I (Irvington-on-Hudson, Transnational Publishers, 1995) 17-36. See also United Nations Security Council (UNSC) 'Report of the Secretary-General Pursuant to Paragraph 2 of the Security Counsel Resolution 808(1993)' (3 May 1993) UN Doc S/25704; UNSC 'Report of the Secretary-General Pursuant to Paragraph 5 of Security Council Resolution 955 (1994)’ (13 Feb 1995) UN Doc S/1995/134.

9 International Commission on Intervention and State Sovereignty (ICISS), The Responsibility to Protect (Ottawa, International Development Research Centre, 2001) [hereinafter ICISS, 'Responsibility to Protect']. See also Scheffer, Atrocity Crimes (Above n. 3) at 117.

10 See generally A. Hehir, Humanitarian Intervention: an Introduction (London, Palgrave Macmillan, 2010). For a specific account of humanitarian intervention in Kosovo see ibid at 201-20. For a specific account of humanitarian intervention in Somalia see F. Teson, Humanitarian Intervention: An Inquiry into Law and Morality, 3rd edn (Ardsley, Transnational Publishers, 2005) 298 [hereinafter Teson, Humanitarian Intervention].

11 The ideas of Francisco de Vitoria (1483/1486-1546) and Bartolomé de las Casas (1485-1566) led to the approval of the 'New Laws of the Indies for the Good Treatment and Preservation of the Indians'. The New Laws, which abolished native slavery for the first time in European colonial history, were passed to prevent the exploitation of the Indigenous peoples of the Americas by large scale landowners (Encomenderos) by strictly limiting their power and dominion. Franciso de Vitoria extrapolated his ideas of legitimate sovereign power to society at the international level. For him, not only relations between states ought to respect the rights of all, but there was also a common good of the world that was superior to the good of each state. As a result, relations between states had to pass from being justified by force to being justified by law and justice. See the translation of those extracts of Vitoria's works De Indis (1532) and De Jure belli Hispanorum in barbaros (1532) contained in his posthumous work F. de Vitoria and J.B. Scott (ed.), Relectiones Theologicae (New York, London, Oceana Publications, 1917). They were reprinted by the Carnegie Institution of Washington in 1964 with the edition of Ernest Nys, who highlighted his influence over Hugo Grotius. See also B. de las Casas and N. Griffin (tr.), Brevísima relación de la destrucción de las Indias (A Short Account of the Destruction of the Indies) (London, Penguin Classics, 1999). This is a translated version of the 1542 De las Casas work. After the approval of the 1542 New Laws, a debate concerning the treatment of natives of the Indies was held in the Spanish city of Valladolid in 1550 and 1551. It opposed two main positions. On the one hand, Bartolomé de las Casas, Dominican and Bishop of Chiapas, argued that natives of the Indies were free men in the natural order and deserved the same treatment as others, according to Catholic theology. On the other hand, fellow Dominican Juan Ginés Sepúlveda insisted the Indians were natural slaves, and therefore reducing them to slavery or serfdom was consistent with Catholic theology and natural law. The New Laws were kept after the triumph of De las Casas' position. See 
cisco Suarez, leading representative of the School of Salamanca, ${ }^{12}$ underscored that political power originates in the consensus of free wills, and that men are thus entitled to disobey even to the point of deposing an unjust government. ${ }^{13}$ Subsequently, Hugo Grotius,,${ }^{14}$ John Locke, ${ }^{15}$ and the contract theorists of the eighteenth century, developed the notion of sovereignty as responsibility so as to shape it into its current form.

Based on this premise, the humanitarian intervention doctrine, formulated for the first time by Hersch Lauterpacht in the immediate aftermath of World War II, ${ }^{16}$ justifies a right of armed intervention into a state that is unwilling or unable to protect its own population against atrocity crimes. ${ }^{17}$ According

A. Losada, The Controversy between Sepúlveda and Las Casas in the Junta of Valladolid (DeKalb, Northern Illinois University Press, 1971) 280-2. See also B. Keen, The Legacy of Bartolomé de Las Casas (Boulder, Westview Press, 1998) 57-69; D.A. Brading, The First America: the Spanish Monarchy, Creole Patriots, and the Liberal State 1492-1867 (Cambridge, Cambridge University Press, 1991) 80-8; A. Padgen, The Fall of Natural Man: The American Indian and the Origins of Comparative Ethnology (Cambridge, Cambridge University Press, 1982) 109; J. Crow, The Epic of Latin America, 4th edn (Berkeley, University of California Press, 1992).

12 The leading members of the School of Salamanca were Francisco de Vitoria (1486-1546), Domingo de Soto (1494-1560), Martín de Azpilicueta (1491-1486), Tomás de Mercado (15251575) and Francisco Suarez (1548-1617).

13 See in particular F. Suárez, G.L. Williams and H. Davis (tr.), 'Defensio Fidei Catholicae adversus Anglicanae sectae errores (The Defense of the Catholic Faith against the errors of the Anglican)' (1613), in: F. Suarez, Selections from three works of Francisco Suárez, S.J.: De legibus, ac deo legislatore, 1612; Defensio fidei catholicae, et apostolicae adversus anglicanae sectae errores, 1613; De triplici virtute theologica, fide, spe, et charitate, 1621 (London, Oxford, Clarendon Press, 1944) 647-728.

14 This understanding is reflected in Grotius' conception of things that are public and common to all men. See H. Grotius and R. Magoffin (tr.), De Mare Liberum, (1609) (New York, Oxford University Press 1916) 22-44; H. Grotius and F. Kelsey (tr.), Dejure Belli AC Pacis book II (1625) (Gloucestershire, Clarendon Press, 1925) ch 2; see generally H. Lauterpacht, 'The Grotian Tradition in International Law', in: H. Lauterpacht, British Yearbook of International Law (London, New York, Toronto, Oxford University Press, 1946) 1, 27.

15 See, for example, J. Locke, 'The Second Treatise of Government' (1690), in: P. Laslet (ed.), Two Treatises of Government, 3rd edn (Cambridge, Cambridge University Press, 1988) 265.

16 H. Lauterpacht (ed.), Oppenheim's International Law: A Treatise, 6th edn (London, Longmans Green and Company, 1947) 280. See also P. Jessup, A Modern Law of Nations (New York, The Macmillan Company, 1948) 172-74; I. Brownlie, 'Humanitarian Intervention', in: J. Moore (ed.), Law and Civil War in the Modern World (Baltimore, Johns Hopkins University Press, 1974) 217; I. Brownlie, 'The Principle of Non-Use of Force in Contemporary International Law', in: W. Butler (ed.), The Non-Use of Force in International Law (1989) 17.

17 According to its supporters, "humanitarian intervention [is] the proportionate transboundary help, including forcible help, provided by governments to individuals in another state who are being denied basic human rights and who themselves would be rationally willing to revolt against their oppressive government.' See Teson, Humanitarian Intervention (Above n. 10) at 5. See also B.F. Burmester, 'On Humanitarian Intervention: The New World Order and Wars to Preserve Human Rights' (1994) 1 Utah Law Review 269; J. Delbruck, 'A Fresh Look at Humanitarian Intervention Under the Authority of the United Nations' (1992) 67 Indiana Law Journal 887, 897 901; R. Gordon, 'Humanitarian Intervention by the United Nations: Iraq, Somalia, and Haiti' (1996) 31 Texas International Law Journal 43, 44-6; R. Lillich, 'Forcible Self Help Under International Law' (1980) 62 Readings in International Law from the Naval War College Review 129, 134; J. Nafziger, 'Self-Determination and Humanitarian Intervention in a Community of Power' (1991) 20 Denver Journal of International Law and Policy 9, 21-6. For these authors, humanitarian intervention was not unlawful under article 2(4) of the UN Charter because (i) it does 
to its supporters, humanitarian intervention by the United Nations, or by states with or without UN authorisation, is consistent with the principles of sovereignty and territorial integrity embraced in the UN Charter. Such principles, they argued, aim to protect the citizens of states rather than states as entities. ${ }^{18}$ As a result, they cannot apply in favour of states that perpetrate or otherwise fail to prevent atrocity crimes.

Nevertheless, the humanitarian intervention doctrine has been progressively abandoned in the last decade for several reasons. ${ }^{19}$ First, it failed to provide precise criteria to define those circumstances giving rise to the alleged right to armed intervention. ${ }^{20}$ Second, it did not receive broad consensus as many argued that the UN Charter's prohibition on the use of force admits of no exception for humanitarian intervention. ${ }^{21}$ Third, as the notion of humanitarian intervention was limited to reaction to actual atrocity crimes, it left states with no other option than to choose between two undesirable

not violate the territorial integrity of a state, since the purpose of such intervention is not to gain territory or alter an existing border; and (ii) it does not violate the political independence of states because it does not seek to subject the recalcitrant state to the political domination of the intervening state. Moreover, it was in consonance with the Charter's goals of promoting human rights and self-determination. See in particular R. Lillich 'Forcible Self-Help by States to Protect Human Rights' (1967) 53 Iowa Law Review 325, 332-8 [hereinafter Lillich, 'Forcible Self-Help']; R. Lillich, 'Humanitarian Intervention: A Reply to Ian Brownlie and a Plea for Constructive Alternatives', in: J. Moore (ed.), Law and Civil War in the Modern World (Baltimore, Johns Hopkins University Press, 1974) 229 [hereinafter Lillich, 'Humanitarian Intervention']; R. Lillich, 'Intervention to Protect Human Rights' (1969) 15 McGill Law Journal 205 [hereinafter Lillich, 'Intervention']; J.N. Moore, 'Toward an Applied Theory for the Regulation of Intervention', in: J.N. Moore (ed.), Law and Civil War in the Modern World (Baltimore, Johns Hopkins University Press, 1974) 3, 24-5 [hereinafter Moore, 'Toward']; W. Reisman, 'Sovereignty and Human Rights in Contemporary International Law' (1990) 84 American Journal of International Law 866 [hereinafter Reisman, 'Sovereignty'].

18 Lillich, 'Forcible Self-Help' (Above n. 17) at 332-8; Lillich, 'Humanitarian Intervention' (Above n. 17) at 229; Lillich, 'Intervention' (Above n. 17); Moore, 'Toward' (Above n. 17) at 24-5; Reisman, 'Sovereignty' (Above n. 17).

19 The theoretical debates over humanitarian intervention are summarised in S. Murphy, Humanitarian Intervention: The United Nations in an Evolving World Order (Washington, DC, PAIL Institute, 1996) 202-12; O. Ramsbotham and T. Woodhouse, Humanitarian Intervention in Contemporary Conflict: A Reconceptualization (Cambridge, Polity Press, 1991) 33-65; D. Richemond, 'Normativity in International Law: The Case of Unilateral Humanitarian Intervention' (2003) 6 Yale Human Rights and Development Law Journal 45, 48-9.

20 See generally R. Zacklin, 'Beyond Kosovo: the United Nations and Humanitarian Intervention', in : L.C. Vorah, F. Pocar, Y. Fetherstone, O. Fourney, C. Graham, J. Hocking and N. Robson (eds.), Man's Inhumanity to Man (The Hague, Kluwer Law International, 2003) 935; T. Franck, 'Legality and Legitimacy in Humanitarian Intervention', in: T. Nardin and M.S. Williams (eds.), Humanitarian Intervention (New York, New York University Press, 2006) 143.

21 M. Akehurst, 'Humanitarian Intervention', in: H. Bull (ed.), World Politics (Oxford, Clarendon Press, 1984) 95, 104-7; I. Brownlie, International Law and the Use of Force by States (Oxford, Claredon Press, 1963) 338-42. See also N. Ronzitti, Rescuing Nationals Abroad Through Military Coercion and Intervention on Grounds of Humanity (Dordrecht, Martinus Nijhoff Publishing, 1985) 
choices: (i) standing by in the face of mounting civilian deaths; or (ii) deploying military force to protect the threatened populations. ${ }^{22}$

With the loss of support for the humanitarian intervention doctrine and the structural limitations of ex-post facto judicial institutions, there was a need to identify new effective mechanisms for preventing atrocity crimes. The notion of responsibility to protect, endorsed by the UN General Assembly at the 2005 World Summit, ${ }^{23}$ reaffirmed by the UN Security Council in $2006,{ }^{24}$ and further elaborated on by the UN Secretary-General in 2009, aims at fulfilling this role..$^{25}$

Like the humanitarian intervention doctrine, the notion of responsibility to protect is based on the understanding of sovereignty as responsibility. Nevertheless, it has several distinctive features, which, as Carsten Stahn has pointed out, ${ }^{26}$ have secured its broad acceptance in a short period of time. First, it addresses the dilemma of intervention from the perspective of those

22 UNGA, On Responsibility to Protect (Above n. 2) at paras 5-6. Moreover, as highlighted by the ICISS, 'external military intervention for humanitarian protection purposes has been controversial both when it has happened - as in Somalia, Bosnia and Herzegovina and Kosovo - and when it has failed to happen, as in Rwanda.' ICISS, 'Responsibility to Protect' (Above n. 9) at 7.

23 In response to Kofi Annan's question at the 2000 Millennium address, the Canadian Government established an ICISS, which, under the chairmanship of Gareth Evans and Mohamed Sahnoun, left aside the controversial doctrine of humanitarian intervention to focus on the new emerging notion of responsibility to protect. ICISS, 'Responsibility to Protect' (Above n. 9) was issued in December 2001. For an insider account of the work of the Commission and the ideas that shaped it, see G. Evans, The Responsibility to Protect: Ending Mass Atrocity Crimes Once and for All (Washington, D.C., Brookings Institution Press, 2008). See also A. Bellamy, A Responsibility to Protect: the Global Effort to End Mass Atrocities (Cambridge, Polity Press, 2009); R. Thakur, The United Nations, Peace and Security: From Collective Security to the Responsibility to Protect (Cambridge, Cambridge University Press, 2006) 245-86; T. Weiss and D. Hubert, The Responsibility to Protect: Research, Bibliography and Background (Ottawa, International Development Research Centre, 2001); R. Thakur, 'Outlook: Intervention, Sovereignty and the Responsibility to Protect Experience from ICISS' (2002) 33 Security Dialogue 323. The notion of responsibility to protect was subsequently endorsed by the UN Secretary-General's (UNSG) High-Level Panel on Threats, Challenges and Change (see UNSG's High-Level Panel on Threats, Challenges and Change, 'A more secure world: Our shared responsibility’ (2 Dec 2004) UN Doc A/59/565 paras 65-6). On 16 September 2005, the UN General Assembly in the framework of the 2005 World Summit approved, by consensus, the concept of responsibility to protect in relation to atrocity crimes. (UNGA '2005 World Summit Outcome'(24 Oct 2005) UN Doc Res A/Res/60/1 paras 138-9 [hereinafter UNGA Res A/Res/60/1]). The General Assembly adopted the Summit Outcome in its resolution. Ibid at para 138 .

24 In Paragraph 4 of UNSC Resolution (Res) 1674 (2006) (28 Apr 2006) UN Doc S/RES/1674, on the protection of civilians in armed conflict, the Security Council reaffirmed the provisions of paragraphs 138 and 139 of the Summit Outcome regarding the responsibility to protect populations from genocide, war crimes, ethnic cleansing and crimes against humanity. In the second preambular paragraph of UNSC Res 1706 (2006) (31 Aug 2006) UN Doc S/Res/1706 on the crisis in Darfur, the Council recalled its earlier reaffirmation of those provisions.

25 UNGA, On Responsibility to Protect (Above n. 2). See also C. Joyner, 'The Responsibility to Protect: Humanitarian Concern and the Lawfulness of Armed Intervention' (2007) 47 Virginia Journal of International Law 693, 709.

26 C. Stahn, 'Responsibility to Protect: Political Rhetoric or Emerging Legal Norm?' (2007) 101 The American Journal of International Law 99, 101, 118. 
suffering atrocity crimes rather than from the perspective of those asserting a right to intervention. ${ }^{27}$

Second, it does not limit responsibility and intervention to reaction to actual atrocity crimes. On the contrary, the notion of responsibility to protect constitutes a holistic approach to address crisis situations ${ }^{28}$ based on the premise that an effective response requires a continuing intervention that starts with the adoption of preventative measures. ${ }^{29}$ Only if such measures fail, reaction to actual atrocity crimes will be needed. ${ }^{30}$ Moreover, the determination of the most appropriate mechanisms for reaction, including military intervention, must be driven by the need to subsequently fulfil the commitment to build a long-lasting peace, and promote good governance, rule of law and sustainable development. ${ }^{31}$

Third, the notion of responsibility to protect is based on a complementarity approach with three main Pillars. According to Pillar I, states whose populations may be at risk have the primary responsibility to protect them from the incitement and commission of atrocity crimes. ${ }^{32}$ When states concerned are unable to do so because of capacity deficits or lack of territorial control, third states, as well as the international community at large, must support and assist them under Pillar II. ${ }^{33}$ If assistance measures are of no use

27 Ibid. at 103.

28 The need for a multiphased vision of international engagement became evident during the multidimensional UN peacekeeping of the 1990s. Secretary-General Boutros-Ghali developed a tripartite conception of peacemaking, which distinguished peace-preventative diplomacy, peacemaking and 'post-conflict peace building' in his Agenda for Peace. See UNSG, 'An Agenda for Peace-Preventative Diplomacy, Peacemaking, and Peace-Keeping' (17 Jun 1992) UN Doc A/47/277-S/24111 para 5. Some aspects of this distinction were subsequently developed in other reports. See for instance, the (i) Brahimi Report, which emphasised the continuous engagement from preventive action to peace building (UNGA and UNSC 'Report of the Panel on United Nations Peace Operations' (21 Aug 2000) UN Doc A/55/305-S/2000/809), and (ii) the 2001 UN Secretary General Report 'No Exit without Strategy', which put the emphasis on post-intervention responsibility (UNSC 'No Exit without strategy: Security Council decision-making and the closure or transition of United Nations peacekeeping operations' (20 Apr 2001) UN Doc. S/2001/394 para 26).

29 UNGA, On Responsibility to Protect (Above n. 2) at paras 1-10.

30 Ibid.

31 Ibid

32 See UNGA, Res A/Res/60/1(Above n. 23) at para 138: 'Each individual State has the responsibility to protect its populations from genocide, war crimes, ethnic cleansing and crimes against humanity. This responsibility entails the prevention of such crimes, including their incitement, through appropriate and necessary means. We [States] accept that responsibility and will act in accordance with it.' As UNGA, On Responsibility to Protect (Above n. 2) at para 18 has explained, Pillar I rests on long-standing obligations under international law, according to which responsibility for the prevention of violations of human rights lies with the national protection system of each state. See also N. Jayawickrama, The Judicial Application of Human Rights Law: National, Regional and International Jurisprudence (Cambridge, Cambridge University Press, 2003) 46-50; B. Ramcharan, 'The National Responsibility to Protect Human Rights' (2009) 39 Hong Kong Law Journal 361, 369-74.

33 See UNGA Res A/Res/60/1(Above n. 23) at para 139: (i) We [States] also intend to commit ourselves, as necessary and appropriate, to helping States build capacity to protect their populations from genocide, war crimes, ethnic cleansing and crimes against humanity and to assisting 
because of the unwillingness of national leadership or the great deficit of national capacity, responsibility devolves to the international community to take timely and decisive action under Pillar III,,${ }^{34}$ including armed intervention in extreme circumstances. ${ }^{35}$

As a result, the notion of responsibility to protect can be said to place a particular emphasis on prevention. ${ }^{36}$ This has led, in turn, to a shift in the focus of the debate from the criteria under which military intervention, with or without $\mathrm{UN}$ authorisation, may be justified, or even required, to the timely implementation of effective preventative measures.

\section{The Two Dimensions of the ICC's Preventative Mandate: General Prevention and Timely Intervention}

As the $21^{\text {st }}$ century has witnessed a change in focus from the humanitarian intervention doctrine to the notion of responsibility to protect, it has also experienced a shift from ex post facto judicial institutions to the establishment and consolidation of a permanent International Criminal Court. As Cherif Bassiouni has underlined, ${ }^{37}$ the ICC represents a rather different approach to the adjudication of atrocity crimes because it: (i) has been created through an international treaty by the States Parties; (ii) constitutes an independent international organisation with a permanent nature ${ }^{38}$; and (iii) is not part of a broader post-conflict UN strategy. ${ }^{39}$

those which are under stress before crises and conflicts break out.'; and (ii) 'The international community, through the United Nations, also has the responsibility to use appropriate diplomatic, humanitarian and other peaceful means, in accordance with Chapters VI and VIII of the Charter, to help to protect populations from genocide, war crimes, ethnic cleansing and crimes against humanity.' Moreover, according to paragraph 140 of the same resolution: 'We [States] fully support the mission of the Special Adviser of the Secretary-General on the Prevention of Genocide.'

34 UNGA Res A/Res/60/1(Above n. 23) at para 139: 'In this context, we are prepared to take collective action, in a timely and decisive manner, through the Security Council, in accordance with the Charter, including Chapter VII, on a case-by-case basis and in cooperation with relevant regional organizations as appropriate, should peaceful means be inadequate and national authorities are manifestly failing to protect their populations from genocide, war crimes, ethnic cleansing and crimes against humanity.'

35 UNGA, On Responsibility to Protect (Above n. 2) at 40, 50, 56.

36 Ibid. at 1-2.

37 M.C. Bassiouni, 'The Making of the International Criminal Court', in: M.C. Bassiouni (ed.), International Criminal Law vol 3, 3rd edn (Leiden, Martinus Nijhoff Publishers, 2008) 117-53.

38 UNGA 'Rome Statute of the International Criminal Court' (17 Jul 1998) UN Doc A/Conf.183/9 arts 1, 4 [hereinafter ICC Statute].

39 The ICC has its own political and financial organs, which include an Assembly of States Parties, as well as a Bureau and a Secretariat of the Assembly, and a Budget and Finance Committee (See art 112 ICC Statute; Assembly of States Parties, 'ICC Financial Regulations and Rules,' ICC-ASP/7/5 (21 Nov 2008). Moreover, as provided for in art. 4 ICC Statute, it has international legal personality, and the necessary legal capacity for the exercise of its functions and the fulfilment of its purposes. 
In particular, the ICC has been established with a view to act over situations of atrocity crimes that take place after $1^{\text {st }} J u l y ~ 2002^{40}$ in the territory of any of its 114 States Parties, ${ }^{41}$ and even outside such territory when there is a substantial involvement of their nationals ${ }^{42}$ or a UN Security Council's referral. ${ }^{43}$ Furthermore, the ICC operates on the basis of a complementarity regime, according to which it can only exercise its jurisdiction when states are inactive, or are unwilling or unable to genuinely carry out their own national proceedings. ${ }^{44}$

There is a clear connection between the notion of responsibility to protect and the ICC's mandate as both have their focus on future situations of atrocity crimes,${ }^{45}$ and are based on the primary responsibility of the states concerned. Indeed, last year, UN Secretary-General Ban Ki-moon referred to the ICC Statute as 'one of the key instruments relating to the responsibility to protect. ${ }^{46}$

In this regard, it must be noted that the ICC shares with ex post facto judicial institutions a commitment to ending impunity as a means to promote: (i) positive general prevention, consisting of upholding the application of international criminal law and reinforcing the core societal values protected therein; and (ii) negative general prevention or deterrence, resulting from sending the message to the world's leadership that those engaging in atrocity crimes will not get away with them. ${ }^{47}$ Such commitment is fulfilled by combining judicial proceedings with a number of external relations, outreach and public information activities. ${ }^{48}$ The ICC's efforts on general prevention may assist UN officials and other stakeholders to emphasise, under Pillars II and III of the notion of responsibility to protect, both the costs of engaging in atrocity crimes and the benefits of abandonment. ${ }^{49}$

Nevertheless, unlike ex post facto judicial institutions, the ICC's preventative mandate has a second dimension. It consists of timely intervention into

\footnotetext{
See art. 11 ICC Statute.

See art. 12 ICC Statute.

See art. 12 ICC Statute.

See arts. 12, 13 (b) ICC Statute.

See Para 10 of the Preamble ICC Statute; arts 1, 17 ICC Statute. See also Situation in the Democratic Republic of the Congo (Judgment on the Appeal of Mr. Germain Katanga against the Oral Decision of Trial Chamber II of 12 June 2009 on the Admissibility of the Case) ICC-01/04-01/07 0A 8 (25 Sep 2009).

45 The notion of responsibility to protect is confined to four specific crimes (genocide, crimes against humanity, war crimes and ethnic cleansing), which, along with the crime of aggression, also constitute the jurisdiction ratione materiae of the ICC (Art. 5 ICC Statute). Nevertheless, it is important to highlight that the International Commission on Intervention and State Sovereignty envisioned the notion of responsibility to protect as having a significantly wider scope (See ICISS, 'Responsibility to Protect' (Above n. 9)). On the controversy about the potential for a wider scope for the notion of responsibility to protect, see Scheffer, 'Atrocity Crimes' (Above n. 3) at 113-6.

46 UNGA, On Responsibility to Protect (Above n. 2), at para 19.

47 Cryer, An Introduction (Above n. 7) at 22-39.

48 ICC, 'Outreach', < www.icc-cpi.int/Menus/ICC/Structure+of+the+Court/Outreach>.

49 UNGA, On Responsibility to Protect (Above n. 2) at paras 19, 53.
} 
situations where there are tangible threats of future atrocity crimes, or where atrocity crimes are already taking place. It is mainly discharged by the ICC Prosecutor through his preliminary examinations and investigations, and may cover a broad range of situations as shown by: (i) the 9000 communications received to-date by the Prosecutor from individuals located in more than 140 countries; ${ }^{50}$ and (ii) the variety of geographical locations in which preliminary examinations or investigations have been started since 2003: Afghanistan, Central African Republic, Colombia, Darfur, Democratic Republic of Congo, Georgia, Guinea, Iraq, Ivory Coast, Kenya, Palestine, Uganda and Venezuela. ${ }^{51}$

As the notion of responsibility to protect places the emphasis on prevention through timely intervention, the ICC's timely intervention can make a unique contribution to discharging the responsibility of the international community under Pillars II and III of the said notion.

\section{The ICC's Timely Intervention as a result of Tangible Threats of Future Atrocity Crimes}

Atrocity crimes are not unavoidable. They take long planning and preparation, as they require a 'collective effort' and an 'organisational context'. ${ }^{52}$ Moreover, there is usually sufficient information about impending atrocity crimes, which, regrettably, is ignored or minimised by high-level national and international decision makers with competing political agendas ${ }^{53}$ Hence, statutory provisions on planning, preparation, incitement and attempt are of the utmost relevance for the effectiveness of preventative efforts through timely intervention. It may thus come as no surprise that, except for the definition of genocide which has always been taken verbatim from the 1948 Genocide Convention, ${ }^{54}$ the approach taken by the ICC Statute is rather

50 To date the ICC Prosecutor has received 8733 individual communications. See ICC, 'Communications, Referrals, and Preliminary Examinations' <www.icc-cpi.int/Menus/ICC/Structure + of + the+Court/Office+of+the+Prosecutor/ Comm+and+Ref/Communications+and+Referrals.htm $>$.

51 Ibid.

52 K Ambos, 'Epilogue: Future Developments of International Criminal Law in relation to the Responsibility of Superiors for International Crimes', in: H. Olásolo, The Criminal Responsibility of Senior Political and Military Leaders as Principals to International Crimes (London, Hart Publishers, 2009) 333.

53 UNGA, On Responsibility to Protect (Above n. 2) at para 6.

54 Genocide is the only exception as its definition, including the references to conspiracy, incitement and attempt, has been taken verbatim by the statutes of ex post facto judicial institutions, such as the ICTY, the ICTR and the Special Court for Sierra Leone, from the language of the 1948 Convention for the Prevention and Punishment of the Crime of Genocide, which expressly criminalises in its article 3 conspiracy to commit genocide, direct and public incitement to commit genocide and attempt to commit genocide. See also J. Ohlin, 'Attempt to Commit Genocide', in: P. Gaeta (ed.), The UN Genocide Convention: A Commentary (Oxford, Oxford University Press, 2009) 183 [hereinafter Ohlin, 'Attempt']; A. Eser, 'Individual Criminal Responsibility', in: 
different than that taken by the statutes of the ex post facto judicial institutions. In the latter, as William Schabas has explained, provisions on planning, preparation, incitement and attempt would simply have been superfluous and were not included. ${ }^{55}$

Article 25 of the ICC Statute provides for liability for attempt in relation to all atrocity crimes (not just genocide), and attaches such liability to 'action that commences the execution of a crime by means of a substantial step'.$^{56}$ Although this definition requires more than just planning, the question arises as to where to draw the line between mere preparatory acts, and conduct amounting to a substantial step for the execution of atrocity crimes. ${ }^{57}$ Neither the ICC Statute nor the case law of international tribunals provide guidance on this matter. ${ }^{58}$ Some national systems, such as Germany's, have taken a more restrictive approach and require a direct movement towards the completion of the crime. ${ }^{59}$ Others, such as the United States' (US), favour a broader conception by attaching liability for attempt to the possession, collection or fabrication of the means of the crime or the tracking of the victims of the crime. ${ }^{60}$

As a result, should the ICC case law embrace a less restrictive approach, liability for attempt may encompass situations such as that which occurred in Rwanda, where for sixteen consecutive months starting in January 1993, more than half a million machetes were imported and distributed, along with firearms and grenades, under the guise of a self-defence programme. ${ }^{61}$

Article 25 of the ICC Statute also attaches criminal liability to acts of 'public and direct incitement to commit genocide'. ${ }^{2}$ Despite its limitation to the crime of genocide, its scope of application may be significant in situations like that in Rwanda where, starting in 1991, the media systematically

A. Cassese, P. Gaeta, J.R.W.D. Jones (eds.), Rome Statute of the International Criminal Court: A Commentary, vol I (Oxford, Oxford University Press, 2002) 807 [hereinafter Eser, 'Individual']; K. Ambos, 'Article 25 Individual Criminal Responsibility', in: O. Triffterer (ed.), Commentary on the Rome Statute of the International Criminal Court, 2nd edn (Oxford, Munich, Hart Publishing and Verlag CH Beck, 2008) 764 [hereinafter Ambos, 'Individual Criminal Responsibility']

55 W.A. Schabas, Genocide in International Law (Cambridge, Cambridge University Press, 2000) 281 [hereinafter Schabas, Genocide].

56 See art. 25 (3) (f) ICC Statute.

57 Ohlin, 'Attempt' (Above n. 54) at 178.

58 Ibid. at $178,182-4$

59 See StGB § 22 (Germany). See also Eser, 'Individual' (Above note 54) at 812.

60 See United States Model Penal Code $\$$ 5.01(1)(c). See also G.P. Fletcher, Rethinking Criminal Law, 2nd edn (New York, Oxford University Press, 2000) 180

61 Prosecutor v. Nahimana et al. (Judgement and Sentence) ICTR-99-52-T (3 Dec 2003) para 113.

62 Regardless of whether genocide actually takes place. See in this regard Prosecutor v. Akayesu (Judgement) ICTR-96-4-T (2 Sep 1998) para 561. See also J. Ohlin, 'Incitement and Conspiracy to Commit Genocide', in: P. Gaeta (ed.), The UN Genocide Convention: A Commentary (Oxford, Oxford University Press, 2009) 192-5. See in particular art. 25 (3)(e) ICC Statute. In this particular area, the ICC Statute is somewhat more restrictive than the Genocide Convention, as well as than the statutes of the other international and internationalised courts and tribunals, which, although limited to the crime of genocide, provided the notion of 'conspiracy'. 
incited Hutus to perpetrate violence against Tutsis, ${ }^{63}$ or like that in Cambodia, where for years, the radio of the Khmer Rouge urged listeners to 'purify' the 'masses of the people' of Cambodia. ${ }^{64}$

With regards to the crime of aggression, the definition approved in June 2010 at the first ICC Review Conference, attaches criminal liability to the 'planning' and 'preparation' of an act of aggression. ${ }^{65}$ This brings the ICC Statute more in line with most national systems, in which criminal liability can arise as a result of agreeing to commit a crime, participating in the design of a criminal plan or contributing to establish the necessary conditions for its execution. ${ }^{66}$ Indeed, if today it is broadly accepted at the national level that criminal liability arises for such preparatory acts, there is no justification to say otherwise at the international level in relation to offences of the magnitude and gravity of atrocity crimes. ${ }^{67}$

Although the existing provisions on attempt and incitement provide a sufficient basis for the ICC's timely intervention, extending liability for

63 Prosecutor v. Nahimana et al (Judgement) ICTR-99-52-A (28 Nov 2007) paras 41, 45. See also J.P. Chrétien, Rwanda: Les Medias du Génocide, 2nd edn (Paris, Karthala/Reporters sans Frontiers, 2002). In particular, despite several reports during those critical months by the United Nations Assistance Mission in Rwanda and the Special Rapporteur on extrajudicial, arbitrary or summary executions on the incendiary programming of Radio des Mille Collines, there was no attempt by the international community to jam such broadcasts. See the UNSC, 'Report of the Secretary-General on the Situation in Rwanda' (31 May 1994) UN Doc S/1994/640 para 11; UNSG, 'Letter Dated 15 December 1999 From the Secretary-General addressed to the President of the Security Council' (16 Dec 1999) UN Doc S/1999/1257, enclosure, annex I; UN Commission for Human Rights, 'Report of the Special Rapporteur on Extrajudicial, Arbitrary or Summary Executions, Mr B.W. Ndiaye, on his Mission to Rwanda from 8 to 17 April 1993' (11 Aug 1993) E/CN.4/1994/7/Add.1.

64 British Broadcasting Corporation, 'Summary of World Broadcasts' FE/5813/A3/2 (15 May 1978).

65 See Assembly of States Parties, 'Amendments to the Rome Statute of the International Criminal Court' Resolution RC/Res. 6 (11 Jun 2010) Annex I, art. 8 bis, para 1.

66 The extension of the scope of criminal law at the national level to criminalise this type of conduct, regardless of whether the commission of the crime is subsequently completed or even started, has been, to an important extent, utilised to confront situations in which a plurality of persons acting in a concerted manner resort systematically to criminal conduct to achieve economic goals (e.g. trafficking of human beings, drugs, weapons, money laundry) or political goals (e.g. terrorism). As a result, it may come as no surprise that national jurisdictions have also extended the criminalisation of preparatory acts to atrocity crimes, which, in addition to constituting the most egregious attacks on the core societal values of the international community, are of a 'unique magnitude', have a 'collective nature' and take place in an 'organisational context'.

67 See on this point the different approaches taken by Cassese and Fletcher on this point in relation to conspiracy to commit genocide: A. Cassese, 'Jurisdiction ratione materiae - Genocide', in: A. Cassese, P. Gaeta, and J.R.W.D. Jones (eds.), The Rome Statute of the International Criminal Court: A Commentary (Oxford, Oxford University Press, 2002) 347; G.P. Fletcher, 'Amicus Curiae Brief of Specialists in Conspiracy and International Law in Support of Petitioner' 2006 West Law 53979, filed in Hamdan v. Rumsfeld, 548 U.S. 557 (2006) 12. Moreover, according to Schabas the exclusion of conspiracy to commit genocide from the Rome Statute was due to 'an oversight of exhausted drafters' (Schabas, Genocide (Above n. 55) at 264). 
'planning' and 'preparation' to all atrocity crimes will significantly strengthen the ICC's preventative role. ${ }^{68}$

Moreover, as senior leaders are usually directly involved in the planning and preparation of atrocity crimes ${ }^{69}$ focusing on this early stage of the iter criminis will reduce the controversy over some forms of criminal liability underscored by Kai Ambos, ${ }^{70}$ George Fletcher ${ }^{71}$ Göran Sluiter ${ }^{72}$ Herman van der Wilt, ${ }^{73}$ Elise van Sliedregt, ${ }^{74}$ Tomas Weigend, ${ }^{75}$ or Gerard Werle. ${ }^{76}$

Furthermore, this will be in line with the ICC's gravity threshold, and Luis Moreno-Ocampo's policy of focusing on the 'most responsible persons'.77

As long as an individual communication ${ }^{78}$ or a referral letter ${ }^{79}$ contains tangible indicia of attempt or incitement to commit atrocity crimes, the ICC

68 In particular, the exclusion of the notion of conspiracy from the realm of art. 25(3) ICC Statute (including in relation to the crime of genocide) appears to be unjustified, particularly in light of its broad acceptance in national legal systems for lesser crimes. The rationale for the criminalisation of the notion of conspiracy is that the design of a common plan to commit a serious offence by two or more individuals seriously increases the risk of harming the societal value which is affected when the relevant offence is committed. This risk is further increased when those who have designed the plan to commit the offence begin taking the first steps towards preparing to implement their criminal plan. Logically, the higher the hierarchical position of those involved in the planning of the crime, the higher the level of risk will be. Likewise, the more egregious an attack on a core societal value is, the more legitimate an intervention at an earlier stage of the iter criminis in order to prevent the commission of the crime will be. As a result, it appears that the notion of conspiracy is particularly well-suited to prevent the actual completion of atrocity crimes (the most serious crimes of international concern) by senior political and military leaders. In light of these circumstances, and considering the inclusion of conspiracy in the Genocide Convention, in the statutes of the ad hoc tribunals and in national jurisdictions, its exclusion from the ICC appears to be unjustified. This is more so if we consider that the definition of the crime of aggression, approved in June 2010 at the first ICC Review Conference, includes the criminalisation of conspiracy-like preparatory acts, such as 'planning'

69 This situation is normally accompanied by the conscious acquiescence of another sector of the leadership, which refrains from active involvement but does not take the measures within their power to stop such plans and/or preparations.

70 K. Ambos, 'Joint Criminal Enterprise and Command Responsibility' (2007) 5 Journal of International Criminal Justice 159, 167-76.

71 G. Fletcher and J. Ohlin, 'Reclaiming Fundamental Principles of Criminal Law in the Darfur Case' (2005) 3 Journal of International Criminal Justice 539.

72 A. Zahar and G. Sluiter International Criminal Law: A Critical Introduction (Oxford, Oxford University Press, 2007) 221-57.

73 H. van der Wilt, 'Joint Criminal Enterprise Possibilities and Limitations' (2007) 5 Journal of International Criminal Justice 91

74 E. van Sliedregt, 'Joint Criminal Enterprise as a Pathway to Convicting Individuals for Genocide' (2007) 5 Journal of International Criminal Justice 184

75 T. Weigend, 'Intent, Mistake of Law and Co-Perpetration in the Lubanga Decision on Confirmation of Charges' (2008) 6 Journal of International Criminal Justice 471.

76 G. Werle, 'Individual Criminal Responsibility in Article 25 ICC Statute' (2007) 5 Journal of International Criminal Justice 953.

77 See ICC Office of the Prosecutor, 'Paper on Some Policy Issues before the Office of the Prosecutor' (Sep 2003) <www.icc-cpi.int/NR/rdonlyres/1FA7C4C6-DE5F-42B7-8B25-60AA962ED8B6/ 143594/030905 Policy Paper.pdf>.

78 See arts 13(c), 15(1) ICC Statute.

79 See arts 13(a) and (b), 14, 53(1) ICC Statute. 
Prosecutor must initiate a preliminary examination. ${ }^{80}$ This examination aims to distinguish between (i) those situations that require a formal investigation, and (ii) those other situations better dealt with by other means. ${ }^{81}$ To make such a determination, it is not sufficient to gather and analyse information concerning the allegations of attempt or incitement. It is also necessary to review the available information regarding inter alia: (i) the admissibility of the relevant situation, due to the inaction, unwillingness or inability of national authorities and the gravity of the violence; and (ii) the possible existence of substantial reasons to believe that the investigation would not serve the interests of justice. ${ }^{82}$

As a result, as Antonio Cassese ${ }^{83}$ and David Scheffer ${ }^{84}$ have pointed out, the Prosecutor can respond appropriately on grounds of admissibility or interest of justice where national authorities take meaningful steps to actually prevent atrocity crimes. Moreover, according to article 25 of the ICC Statute those who start the execution of atrocity crimes by means of a substantial step shall not be liable if they abandon their efforts to commit such crimes or otherwise prevent their completion. ${ }^{85}$ Hence, the Prosecutor can close a preliminary examination into allegations of attempt or incitement if his timely intervention has contributed to successfully defusing the threat of atrocity crimes occurring.

80 Not only all natural and legal persons have been granted the right to access the ICC by way of individual communications and, in the case of States Parties and the Security Council, referral letters, but they have also been granted the right to be informed of the reasons why the ICC Prosecutor does not intend to proceed with an investigation. See arts 15(6), 53(3) ICC Statute and Rules 104 and 105 of the Rules of Procedure and Evidence. See also H. Olásolo, The Triggering Procedure of the International Criminal Court (The Hague, Martinus Nijhoff Publishers, 2005) 65-70 [hereinafter Olásolo, Triggering Procedure]

81 Olásolo, Triggering Procedure (Above n. 80) at 39-47. See also ICC Presidency, 'Regulations of the Office of the Prosecutor' ICC-BD/05-01-09 (23 Apr 2009), regulations 25-9.

82 According to arts 15(3) and (4), 53(1) ICC Statute, and Rule 48 of the Rules of Procedure and Evidence, these are the different elements of the standard 'reasonable basis to initiate an investigation', which must be met for the ICC to initiate a formal investigation into a situation. This was underscored in the recent decision of Pre-Trial Chamber II in the relation to the Kenya situation. Situation in the Republic of Kenya (Decision Pursuant to Article15 of the Rome Statute on the Authorization of an Investigation into the Situation in the Republic of Kenya) ICC-01/09-19 (31 Mar 2010) paras 26-35.

83 A. Cassese, International Criminal Law (Oxford, Oxford University Press, 2008) 395-409.

84 D. Scheffer and A. Cox, 'The Constitutionality of the Rome Statute of the International Criminal Court' (2008) 98 Journal of Criminal Law and Criminology 983-1068.

85 According to art. 25(3)(f) ICC Statute: 'Attempts to commit such a crime by taking action that commences its execution by means of a substantial step, but the crime does not occur because of circumstances independent of the person's intentions. However, a person who abandons the effort to commit the crime or otherwise prevents the completion of the crime shall not be liable for punishment under this Statute for the attempt to commit that crime if that person completely and voluntarily gave up the criminal purpose.' See Ambos, 'Individual Criminal Responsibility' (above n. 54) at 764. See also Ohlin, 'Attempt' (Above n. 54), at 175-7. 
Although the Prosecutor cannot rely at this stage on measures of a coercive nature, ${ }^{86}$ and not all forms of States Party cooperation are available,${ }^{87}$ the potential of preliminary examinations to incentivise national authorities should not be underestimated. As shown by several preliminary examinations, including Georgia, ${ }^{88}$ Guinea, ${ }^{89}$ and Palestine, ${ }^{90}$ the Prosecutor, in addition to receiving testimony and seeking information from reliable sources, ${ }^{91}$ may: (i) send missions to the relevant states; (ii) receive in The Hague national delegations of members of governments, representatives of high-courts, opposition leaders and NGOs; (iii) provide advice on those measures that should be taken at the national level to defuse the threat of atrocity crimes; (iv) discuss a prevention strategy with the United Nations and other stakeholders; (v) exchange information with national and inter-

86 Upon the initiation of an investigation, the Prosecutor can also rely on measures of a coercive nature, as well as on all forms of State Party cooperation provided for in Article 93 of the ICC Statute. See arts 54, 57, 93 ICC Statute. Disguising an article 54 ICC Statute investigation as an article 15(2) ICC Statute preliminary examination would be contrary to the limited scope of the latter. See Olásolo, Triggering Procedure (Above n. 80) at 59. A different opinion is held by M. Bergsmo and J. Pejic, 'Article 15', in: O. Triffterer (ed.), Commentary on the Rome Statute of the International Criminal Court, 2nd edn (Oxford, Munich, Hart Publishing and Verlag CH Beck, 2008) 366 .

87 Those forms of State Party cooperation provided for in Article 93 RS in which the Prosecution can rely on at this stage are: (i) the identification and location of persons or items; (ii) the voluntary questioning of victims and witnesses in the territory of the States Parties; (iii) the service of documents, including judicial documents; (iv) the provision of records and documents, including official records and documents; (v) the examination of places or sites; and (vi) any other type of assistance not of a coercive nature which is not prohibited by the law of the requested Statute. See Olásolo, Triggering Procedure (Above n. 80) at 60.

88 In relation to the preliminary examination of the situation in Georgia, since the Prosecutor made its preliminary examination public on 14 August 2008, the Georgian Minister of Justice visited the Prosecutor in the Hague; Russia, a State not Party to the Statute, sent to the Prosecutor 3,817 communications, the Prosecutor requested information from the Governments of Russia and Georgia on 27 August 2008, and both of them responded; and two on-site visits have been conducted in Georgia in November 2008 and June 2010, and one in Russia in March 2010. See ICC Office of the Prosecutor, 'Georgia' <www.icc-cpi.int/Menus/ICC/Structure+of+the+Court/ Office+ + of + the + Prosecutor/Comm + And + Ref/Georgia/ $>$.

89 In relation to the preliminary examination of the situation in Guinea, since the Prosecutor made public its preliminary examination on 14 October 2009, consultations were held in January 2010 with President Compaore of Burkina Faso (mediator for the contact group on Guinea) and President Wade of Senegal to ensure that they are informed of Prosecutor's work; two on-sites visits to Guinea have taken place in February and May 2010 to meet inter lia with the Guinean Minister of Justice, Colonel Lohalamou, and the Guinean judges took place on 19-21 May 2010. See ICC Office of the Prosecutor, 'Guinea' <www.icc-cpi.int/Menus/ICC/Structure+of+the+ Court/Office+ + of + the+Prosecutor/Comm+and+Ref/Guinea/ $>$.

90 With regard to the preliminary examination of the Palestine situation, a delegation from the Palestinian National Authority, and Representatives of the Arab League visited the Prosecutor on 15 and 16 October 2009, and on 11 January 2010. See ICC Office of the Prosecutor, 'Palestine' $<$ www.icc-cpi.int/Menus/ICC/Structure + of + the + Court/Office + of + the+Prosecutor/Comm + and + Ref/Palestine/>.

91 Art. 15(2) ICC Statute; Rules 104, 105 of the Rules of Procedure and Evidence. 
national actors; and (vi) address in the media the evolution of events and the degree of cooperation by national authorities. ${ }^{92}$

Using diplomatic and media channels to bring the world's attention to the plans of senior leaders to engage in atrocity crimes, along with highlighting the possibility of them escaping ICC prosecution should they abandon their plans and take the necessary preventative measures, can be a powerful tool. Moreover, from the perspective of ensuring a timely reaction to tangible threats of atrocity crimes, the ICC Statute appears to offer unprecedented opportunities. While other organs of the international community, such as the UN Security Council or the UN General Assembly, usually require long negotiations before deciding to intervene in a situation, the ICC Prosecutor need not consult with interested stakeholders prior to opening a preliminary examination.

Despite the absence of conclusive evidence at this stage, it appears that the preliminary examination in Afghanistan, contributed to NATO (and in particular the United States) subsequently tightening its airstrike policy. ${ }^{93}$ The United States also appears to have reaffirmed its commitment to its internal mechanisms of investigation and prosecution, ${ }^{94}$ which may have led to the opening in April 2010 of a high profile military inquiry into civilian deaths allegedly caused by US Special Forces. ${ }^{95}$

In turn, the preliminary examination in Iraq, which started upon the receipt of numerous individual communications since 2003, was closed in light of the proceedings initiated in the United Kingdom with regard to each instance of war crimes allegedly involving British nationals. ${ }^{96}$

Moreover, the preliminary examination in Kenya appears to have strengthened the message sent by former UN Secretary-General Kofi Annan

92 See in this regard, W. Burke-White, 'Implementing a Policy of Positive Complementarity in the Rome System of Justice' (2008) 19 Criminal Law Forum 59, 61 [hereinafter Burke-White, 'Implementing']; C. Hall, 'Developing and Implementing an Effective Positive Complementarity Prosecution Strategy', in: C. Stahn and G. Sluiter, The Emerging Practice of the International Criminal Court (Leiden, Brill, 2009) 220 [hereinafter Hall, 'Developing'].

93 D. Schwammenthal, 'Prosecuting American 'War Crimes'، The Wall Street Journal (The Hague, 26 Nov 2009) Opinion Europe. See also D. Filkins, 'U.S. Tightens Airstrike Policy in Afghanistan' The New York Times (21 Jun 2009) Asia Pacific.

94 See E. Barbour and M.C. Weed, 'The International Criminal Court (ICC): Jurisdiction, Extradition, and U.S. Policy' (Congressional Research Service 16 Mar 2010) <assets.opencrs.com/ rpts/R41116_20100316.pdf>, 15.

95 See L. King, 'Inquiry puts Spotlight on U.S. Special Forces in Afghanistan' The Los Angeles Times (9 Apr 2010) referring to the high profile inquiry into alleged civilian deaths caused by special forces who, until then, had been largely shielded from the public spotlight which was opened by the US military in April 2010.

96 ICC Office of the Prosecutor, 'OTP Response to communications received concerning Iraq' (9 Feb 2010) <www.icc-cpi.int/NR/rdonlyres/04D143C8-19FB-466C-AB77-4CDB2FDEBEF7/143682 OTP_letter_to_senders_re_Iraq_9_February_2006.pdf $>, 9$. 
to caution Kenyan authorities that there will be no impunity for those engaging in atrocity crimes. ${ }^{97}$

Whenever a preliminary examination is unsuccessful in incentivising national authorities, the investigation stage,${ }^{98}$ in which the Prosecutor can rely on coercive measures ${ }^{99}$ and all forms of State Party cooperation, may prove to be a useful mechanism to fulfil the ICC's preventative mandate. Article 53 of the ICC Statute empowers the Prosecutor to close an investigation when 'there is no sufficient basis for a prosecution'. This standard is comprised of similar criteria to those applicable during the preliminary examination. ${ }^{100}$ As a result, the Prosecutor can close an investigation if it has served to prompt reluctant national authorities to take meaningful steps to actually prevent the commission of atrocity crimes. ${ }^{101}$

\section{The ICC's Timely Intervention When Atrocity Crimes Are Already Taking Place}

The ICC's timely intervention can also take place in situations in which atrocity crimes are already occurring. The focus in these situations will be on stopping ongoing atrocity crimes.

Moreover, abandonment of future crimes will not exclude liability for those already committed. Therefore, preliminary examinations and investigations could only be brought to an end by the Prosecutor on admissibility or interest of justice grounds.

97 See the research paper by C. Bjork and J. Goebertus, from Harvard Law School, 'Parallel Paths and Unintended Consequences: The Role of Civil Society and the ICC in Rule of Law Strengthening in Kenya' (forthcoming) works.bepress.com/christine_bjork/1/. See also Kofi Annan Foundation, 'Remarks by Kofi Annan on Conclusion of the Visit to Kenya, 2-8 December 2009' (Press Release Dec 2009) <kofiannanfoundation.org/newsroom/press/2009/12/remarks-he-kofiannan-conclusion-visit-to-kenya-au-panel-eminent-african $>$. Nevertheless, far more empirical research is necessary to have more certainty about the impact of the Preliminary Examination of the ICC.

98 In this cases, a qualitative approach to the gravity threshold may still justify the start of an investigation into a situation where atrocity crimes have not been yet committed, or are starting being committed. For a definition of a qualitative approach to the gravity threshold see Prosecutor v. Abu Garda (Decision on the Confirmation of Charges) ICC-02/05-02/09 (8 Feb 2010) paras 313; Situation in the Republic of Kenya (Decision Pursuant to Article 15 of the Rome Statute on the Authorization of an Investigation into the Situation in the Republic of Kenya) ICC-01/09 (31 Mar 2010) para 62 .

99 See arts 54-7 ICC Statute.

100 Compare art. 53 (2) ICC Statute with art. 53 (1) ICC Statute and rule 48 of the ICC Rules of Procedure and Evidence.

101 Moreover, under article 19, paragraph 11, of the ICC Statute, the Prosecutor may decide to suspend his investigation and monitor the development of events at the national level prior to formally close it. 
In this context, prompting national authorities to stop ongoing atrocity crimes goes hand in hand with: ${ }^{102}$ (i) encouraging and assisting them to comply with their duties to investigate and prosecute those crimes already occurred ('positive complementarity'); ${ }^{103}$ and (ii) dividing with the ICC, particularly in cases of substantial capacity deficits, the burden of adjudicating the crimes ('cooperative complementarity'). ${ }^{104}$ As a consequence, supporting receptive states to strengthen their judicial systems and carry out national proceedings is a core component of the ICC's timely intervention.

As stated by William Burke-White ${ }^{105}$ and Christopher Hall, ${ }^{106}$ the Prosecutor, in order to fulfil this mandate during his preliminary examinations and investigations, may rely on those measures referred to in the previous section. In particular, the Prosecutor may train national actors in the adjudication of atrocity crimes, and may assist them in the establishment of protection programmes for victims and witnesses and effective systems of information management. He can also monitor and provide feedback regarding the development of national proceedings, and work in coordination with other ICC organs to increase the efficacy of overall preventative efforts.

It must be stressed that, despite the international cooperation of other stakeholders, the national authorities of receptive states appear to have a strong preference to receive advice and guidance directly from ICC officials. As national authorities are aware that their efforts to adjudicate atrocity crimes will be reviewed by the ICC, the ICC's advice and guidance is considered of the utmost importance to ensure the success of such efforts. As a result, the potential of the ICC to strengthen through timely intervention the rule of law and improve good governance in receptive states is major. ${ }^{107}$ The

102 Both positive and cooperative complementarity appear to have been implicitly upheld, to an important extent, by the 22 June 2009 decision of the ICC Appeals Chamber in the Katanga and Ngudjolo case. See Prosecutor v Mr Germain Katanga and Mathieu Ngudjolo Chui (Decision on the Presiding Judge of the Appeals Chamber in the appeal of Germain Katanga against the Decision of Trial Chamber I of 12 June 2009 on the admissibility of the case) ICC-01/04-01/07 OA 8 (10 Jul 2009).

103 See Burke-White, 'Implementing' (Above n. 92) at 61; Hall, 'Developing' (Above n. 92) at 220. See also M.E. Cross and S. Williams, 'Recent Developments at the ICC: Prosecutor v. Germain Katanga and Mathieu Ngudjolo Chui: A Boost for Co-operative Complementarity?' (2010) 10 Human Rights Law Review 336, 339.

104 A. Cassese et al., 'The Rome Statute: A Tentative Assessment', in: A. Cassese et al. (eds.), The Rome Statute of the International Criminal Court: A Commentary (Oxford, Oxford University Press, 2002) 1906; C. Kress, "'Self-Referrals" and "Waivers of Complementarity": Some Considerations in Law and Policy' (2004) 2 Journal of International Criminal Justice 944, 947-8; F. Gioia, 'State Sovereignty, Jurisdiction, and "Modern" International Law: The Principle of Complementarity in the International Criminal Court' (2006) 19 Leiden Journal of International Law 1095, 1115.

105 Burke-White, 'Implementing' (Above n. 92) at 61.

106 Hall, 'Developing' (Above n. 92) at 220.

107 See also in this regard, W. Burke-White, 'Complementarity in Practice: The International Criminal Court as Part of a System of Multi-level Global Governance in the Democratic Republic of Congo' (2005) 18 Leiden Journal of International Law 557, 589-90. See also in this respect the document issued by the prosecution itself which was published just after this inaugural address was delivered. ICC Office of the Prosecutor, 'Draft Policy Paper on Preliminary Examinations' (4 Oct 2010) 
preliminary examination in Colombia provides some indicia of this potential. Investigations of those paramilitary members demobilised in Colombia since $2003^{108}$ did not start until May 2006, when the Constitutional Court upheld the centrepiece of the demobilisation process: the Peace and Justice Law. ${ }^{109}$ Soon afterwards, the ICC Prosecutor made public his preliminary examination, ${ }^{110}$ and in October 2007 and August 2008 he personally conducted two on-site visits to Colombia. ${ }^{111}$

Since then, the Supreme Court of Colombia has underscored the importance of focusing investigations under the Peace and Justice Law on (i) the pattern of atrocity crimes committed against the civilian population, and (ii) the structure, membership and external support of those paramilitary organisations through which the crimes were committed. ${ }^{112}$ This has been fully reflected in the sixteen-page Protocol for the Presentation of Evidence issued on 23 August 2010 by the Bogotá Peace and Justice Trial Chamber.

Furthermore, since the end of 2007, the Colombian Supreme Court has also been conducting investigations and prosecutions for alleged links with paramilitary groups against a third of the members of the Colombian Parliament, ${ }^{113}$ as well as against around twenty Governors. ${ }^{14}$ These proceedings, which are based on confessions made by demobilised paramilitary leaders, have led so far to more than ten convictions, most of them against members of political parties that supported the Colombian Government in 2007. Such confessions have also led to the investigation in lower courts of several

<www.icc-cpi.int/NR/rdonlyres/9FF1EAA1-41C4-4A30-A202-174B18DA923C/282515/OTP Draftpolicypaperonpreliminaryexaminations04101.pdf>. At the June 2010 ICC Review Conference, a proposal was made by the stocktaking bureau on the complementarity principle to task the Secretariat of the Assembly of States Parties 'facilitating the exchange of information between the Court, States Parties, signatory States, international organizations, civil society and other stakeholders, aimed at strengthening domestic jurisdictions.' (Bureau on stocktaking: Complementarity, 'Taking Stock of the Principle of Complementarity: Bridging the Impunity Gap' (18 Mar 2010) ICC-ASP/8/51, para. 54 (e)). Although this initiative may constitute an initial first step in the right direction, it is insufficient in light of the potential in strengthening rule of law and improving good governance in receptive states through timely intervention.

108 The demobilisation process is the result of the Santa Fé de Ralito Accord signed on 15 July 2003. That agreement was between the Colombian national government and the so-called Autodefensas Unidas de Colombian (AUC).

109 See Corte Constitucional de Colombia, sentencia C-370/ 2006 (18 May 2006). See also JE Arvelo 'International Law and Conflict Resolution in Colombia: Balancing Peace and Justice in the Paramilitary Demobilization Process' (Winter 2006) 77 Georgetown Journal of International Law 411.

110 See ICC Office of the Prosecutor, 'Colombia' <www.icc-cpi.int/Menus/ICC/Structure+of + the+ Court/Office+of + the + Prosecutor/Comm+and+Ref/Colombia $>$.

111 See ibid.

112 See, inter alia, the appeal decisions of the Penal Chamber of the Colombian Supreme Court, in the cases of (i) Wilson Salazar Carrascal (a.k.a. el loro), Case Num. 31539 (31 Jul 2009); and (ii) Gian Carlos Gutierrez Suarez (a.k.a. el tuerto), Case Num. 32022 (21 Sep 2009).

113 See Verdad Abierta's information collected up to July 2010 which refers to data provided by the New Rainbow Foundation available at <www.verdadabierta.com/reconstruyendo/1856-estadisticas>.

114 Ibid 
hundred civil servants, local politicians and members of the armed forces and the police. ${ }^{115}$

It is indisputable that only a handful of high ranking military and police officers are currently facing investigation, and that the application of the Peace and Justice Law is facing significant challenges, such as (i) the lack of publicity of the criteria to select those demobilised paramilitary members investigated under such a Law; (ii) the few convictions entered so far; (iii) the extradition to the United States on drug-trafficking charges of fourteen key high-level paramilitary leaders; (iv) the lack of demobilisation of guerrilla members; and (v) the new increase in the level of violence, spurred partly by armed groups comprised of former paramilitary members. ${ }^{116}$

Nevertheless, in assessing whether the ongoing Colombian proceedings for atrocity crimes are contributing to strengthening the rule of law and improving good governance, one must take into consideration the long decades of mass violence in which paramilitary groups and their aides enjoyed full impunity in Colombia.

As shown by the visits of the Colombian Attorney General and an ample delegation of the Colombian Supreme Court to the ICC in 2010, the Prosecutor's preliminary examination appears to be a contributing factor to the new situation in Colombia. Nevertheless, it is difficult to measure its impact on the Colombian national authorities as there appear to be several other contributing factors, such as: (i) the conditions imposed by the US Congress to approve US military aid and favourable trade conditions for Colombia; ${ }^{117}$ and

115 Ibid.

116 For a general analysis of the justice and peace process see K. Ambos, Procedimiento de La Ley de Justicia y Paz (Ley de 2005) y Derecho Penal Internacional (Bogotá, GTZ, Universidad de Göttingen, 2010); Comisión Colombiana de Juristas, Anotaciones sobre la Ley de Justicia y Paz: Una Mirada desde los Derechos de las Víctimas (Bogotá, Comisión Colombiana de Juristas, 2007). See also the recent publication by Professor Kai Ambos extended within the framework of the roundtable with non-government organisations on the situationin Colombia in The Hague organised by the Office of the ICC on 19 and 20 October 2010, K. Ambos and F. Huber, 'The Colombian Peace Process and the Principle of Complementarity of the International Criminal Court: Is there sufficient willingness and ability on the part of the Colombian authorities or should the Prosecutor open an investigation now?' (5 Jan 2011) <www.icc-cpi.int/ NR/rdonlyres/ 2770C2C8-309A-408E-A41B-0E69F098F421/282850/civil1.pdf $>$.

117 The final certification by the US State Department in connection with the performance by the Colombian armed forces of the conditions relating to compliance with the conditions of respect for human rights imposed by the United States Congress took place on 9 September 2010. See in this regard, United States Embassy in Bogotá, 'Resolución y Certificación del Gobierno Colombiano y de las Fuerzas Armadas con respect a los Condicionamientos en Derechos Humanos' (15 Sep $2010)<$ spanish.bogota.usembassy.gov/pr_117_15092010.html>. It can also be found on the website of the Colombian Commission of Jurists report by the US State Department which analyses in detail whether or not the Colombian armed forces in 2009 complied with the requirements of respect for human rights imposed by the United States Congress. (US Department of State, 'Memorandum of Justification concerning Human Rights Conditions with respect to Assistance for the Colombian Armed Forces' (Sep 2010) <www.coljuristas.org/ LinkClick.aspx? fileticket $=\mathrm{ksYH} 5 \mathrm{X} 9 \mathrm{Cvy} 0 \% 3 \mathrm{~d} \&$ tabid $=160 \&$ language $=\mathrm{es}-\mathrm{CO})>$. 
the judgments of the Inter-American Court of Human Rights against Colombia for paramilitary violence. ${ }^{118}$

In this context, further coordination between the ICC's timely intervention and those other contributing factors will increase the effectiveness in Colombia of the measures taken by the international community pursuant to the notion of responsibility to protect. In this regard, it must be noted that the need for further coordination between the United Nations and the ICC is especially acute, ${ }^{119}$ particularly in light of their mutual recognition and commitment to cooperation, ${ }^{120}$ as well as the existing safeguards against ICC interference with the role of the Security Council. ${ }^{121}$

118 See the judgments of the Inter-American Court of Human Rights in Case of the 19 Comerciantes vs Colombia, Series C, No 93 (5 Jul 2004); Case of the Mapiripán Massacre vs Colombia, Series C, no 122 (15 Sep 2005); Case of the Pueblo Bello Massacre vs Colombia, Series C, No 140 (31 Jan 2006); Case of the Ituango Massacre, Series C, No 148 (1 Jul 2006); Case of Manuel Cepeda Vargas vs Colombia, Series C, No 213 (26 May 2010).

119 A. Cassese, 'Is the ICC Still Having Teething Problems' (2006) 4 Journal of International Criminal Justice 434, 436. See also N. Jain, 'A Separate Law for Peacekeepers: The Clash between the Security Council and the International Criminal Court' (2005)16 European Journal of International Law 239.

120 Paragraph 7 and 9 of the Preamble of the ICC Statute reaffirms the Purposes and Principles of the UN Charter and emphasises the will of the States Parties to have the ICC established in relationship with UN system. Moreover, article 87 (7) of the Statute permits the ICC to send a finding of lack of state cooperation to the UN Security Council for its consideration. Other provisions, such as article 87 (6) of the ICC Statute, provide that the ICC may ask any intergovernmental organisation, including the United Nations, to provide information or documents, as well as other forms of cooperation agreed upon by the relevant organisation. Furthermore, article 115 of the ICC Statute establishes that the expenses of the Court and the Assembly of States Parties may be provided for by the '[f]unds provided by the United Nations, subject to the approval of the General Assembly, in particular in relation to the expenses incurred due to referrals by the Security Council. In turn, the Negotiated Relationship Agreement between the ICC and the United Nations (elaborated pursuant to article 2 of the ICC Statute) is based on mutual recognition between the UN and the ICC and a commitment to cooperation. Its preamble highlights 'the important role assigned to the International Criminal Court in dealing with the most serious crimes of concern to the international community as a whole [...] and which threaten the peace, security and well-being of the world.' On the basis of a general obligation of mutual cooperation, coordination and consultation enshrined in article 3 , the Negotiated Relationship Agreement elaborates on the modalities of cooperation between both organisations in a number of areas, including UN Security Council referrals (art 17(1) of the Negotiated Relationship Agreement), UN Security Council requests for suspension of ICC investigations and prosecutions (art 17(2) of the Negotiated Relationship Agreement), UN Security Council cooperation under the condition of confidentiality (art 18(3) of the Negotiated Relationship Agreement), and UN Security Council cooperation with the ICC Prosecutor in the context of a preliminary examination (art 18(2) ICC Statute of the Negotiated Relationship Agreement).

121 Articles 12, 13, and 16 of the ICC Statute empower the UN Security Council to refer any post 1 July 2002 situation to the ICC without any jurisdictional limitation, and to request the ICC to suspend an investigation or a prosecution for renewable periods of 12 months.Moreover, the Assembly of States Parties has recently approved by consensus at the First Review Conference that the ICC will only exercise its jurisdiction over the crime of aggression after ascertaining whether the UN Security Council has made a determination of an act of aggression committed by the relevant State. In the absence of such a declaration, the ICC could only proceed if it is acting on the basis of a State Party referral or an individual communication and if the plenary of the Pre-Trial Division gives its authorisation to do so (see Assembly of States Parties, 'Amendments to the Rome Statute of the International Criminal Court on the Crime of Aggression' Annex I to Resolution RC/Res.6 (11 June 2010) art. 15 bis, para 6). 


\section{Conclusion}

The ICC's preventative mandate is an important means to fulfil the responsibility of the international community under the notion of responsibility to protect. So far, the focus has been on the ICC's efforts on general prevention by ending impunity for past atrocities. Nevertheless, the ICC's contribution to the prevention of future atrocity crimes through timely intervention is potentially even greater.

Realising this potential requires acknowledgment of the ICC's preventative role through timely intervention by the different organs of the institution. It also requires States Parties to recognise this role so as to provide the necessary resources, and extend to all atrocity crimes criminal liability for 'planning' and 'preparation'. Based on this premise, increased coordination between the ICC, the United Nations and other stakeholders will increase the preventive effect of their timely intervention.

In the end, what is at stake is whether the ICC remains as one among several mechanisms for accountability with a limited general prevention mandate; or whether, instead, it fully develops its potential to prevent atrocity crimes, strengthen the rule of law and improve good governance through timely intervention.

\section{Acknowledgements}

I would like to thank the Rector Magnificus and the Central Board of Utrecht University for my appointment as chair on international criminal law and international criminal procedure. Thanks are also due to the board of the Faculty of Law, Economics and Governance, and in particular the Department of Law, for the trust it has placed in me by supporting my appointment. I am committed to do my best to fulfill its expectations.

I would like to extend my gratitude and appreciation to the Willem Pompe Institute, the ICC, and the ICTY. In particular, I would like to acknowledge my gratitude to Judge Sylvia Steiner, who has been my boss and my close friend for almost a decade. She will always be unforgettable to me.

I would like to acknowledge Ambassador Juan Antonio Yañez-Barnuevo, Law Professor Maria del Carmen Calvo, William Fenrick and Pieter Kruger for having trust in me, ten years ago, when nobody else did it. My gratitude is also extended to some my colleagues here in Utrecht who have put their trust in a young Spanish professor with a "pirate accent"; John, Ige, Stijn, Francois, Dina, Chrisje, Anne-Marieke, Leo, Eric, Diana, Enrique, Jill and Dessy - thank you very much.

A mis padres Valentín y Mercedes quiero agradecerles el amor y el apoyo desinteresado que siempre me han ofrecido desde el dia en que, gracias a 
ellos, vi la luz por primera vez. Ellos son, sin duda, los verdaderos responsables de aquello que soy hoy.

I also want to thank to my sisters Laura and Ana, who travelled yesterday from Spain to be here today. I am particularly indebted to Laura for her generosity in the most difficult of times, as well as my other siblings, Pablo, José and Elena, who unfortunately cannot be with us today. I wish them happiness and good cheer.

I would like to thank Gordon Brandt, for his invaluable help in preparing this presentation, and Sonia, Edwin, Julian, Ana Maria, Alejandro, Romina, Julieta, Teresa and Salvador who have always supported me, even in the most challenging situations. In particular, I want to extend words of encouragement and support to Sonia who is currently facing serious, but not insurmountable, health problems.

And of course I would like to also thank Paola, who has suffered through the drafting of this inaugural lecture day after day for the last year and half, and has made me believe in love again. For her, I have only two words: 'Te quiero'.

Finally, to all of you for being here on an unforgettable day; I offer my most heartfelt thanks for your presence.

And on that note, following the advice of my dear Gerda Blok and Carin Schnitger, I conclude this inaugural lecture by stating that ' $\mathrm{Ik}$ heb gezegd'. 